\title{
Visual Detection and Determination of Melamine Using Synthetic Dyes
}

\author{
Ramesh Thimmasandra Narayan and Kirana Devarahosahally Veeranna \\ Department of Studies and Research in Chemistry and Prof. C. N. R. Rao Centre for Advanced Materials, Tumkur University, \\ Tumkur 572 103, India \\ Correspondence should be addressed to Ramesh Thimmasandra Narayan; adityaramesh77@yahoo.com
}

Received 7 August 2014; Accepted 7 September 2014; Published 25 September 2014

Academic Editor: Hongxing Dai

Copyright (c) 2014 R. Thimmasandra Narayan and K. Devarahosahally Veeranna. This is an open access article distributed under the Creative Commons Attribution License, which permits unrestricted use, distribution, and reproduction in any medium, provided the original work is properly cited.

\begin{abstract}
We have used spectroscopic technique for the detection of melamine. The effect of melamine on the colour as well as the pH of bromophenol, methyl red and alizarin red dye solutions was examined at different mole ratios. It is found that we observe color transition and the absorption maxima for bromophenol were at $598 \mathrm{~nm}$, while for methyl red, and alizarin red-S dye they are at $520 \mathrm{~nm}$ and $423 \mathrm{~nm}$, respectively. We observe an increase in the absorption intensities at $598 \mathrm{~nm}$ with increase in the concentration of melamine in bromophenol blue dye. The absorption intensities at $520 \mathrm{~nm}$ decreases and new peak at $420 \mathrm{~nm}$ emerges in methyl red dye-melamine mixture. While the absorption intensities at $420 \mathrm{~nm}$ decreases and $520 \mathrm{~nm}$ peak emerges in alizarin red $\mathrm{S}$ dye-melamine at higher mole ratios. The results indicate that we can choose the appropriate dye of suitable range to detect the concentration of melamine from 3 to $206 \mathrm{mg} \mathrm{dm}^{-3}$. The results demonstrate possible use of the simple method for the qualitative and quantitative detection of melamine in adulterated food samples.
\end{abstract}

\section{Introduction}

Melamine is a weak organic base with the chemical formula $\mathrm{C}_{3} \mathrm{~N}_{6} \mathrm{H}_{6}$ which contains $67 \%$ of nitrogen mass. Melamine in combination with formaldehyde produces melamine resin and has been widely used as fire retardant for the release of nitrogen when burned $[1,2]$. Melamine foam has also been employed as a colourant, superplasticizer, polymeric cleansing product, insulator and so forth [3]. In early 1950 and $1960 \mathrm{~s}$, melamine was used as nonprotein food source for ruminants and also as source of nitrogen for food crops [4]. Development of dairy industries in last few decades has resulted in the promotion of adulterating the food products across the world with an ulterior motive to gain higher profits [5]. Several thousand people die every year due to the consumption of adulterated food. One of the classic examples is the sudden death of infants and pets across the world in 2007 and 2008 due to the adulteration of infant milk powder and pet food with melamine [6]. One of the most widely used methods to detect the protein content in the samples is by using Kjeldahl and Dumas test. In this test, nitrogen content will be estimated to obtain information about the protein content [7]. Melamine contains higher percentage of nitrogen content and this promoted the food industries to adulterate the food products with melamine illegally to enhance the apparent nitrogen content in the milk powder during the estimation of protein levels [8]. Alternative techniques used for the detection of melamine are HPLC, GC, MS, IR, Raman, Zone electrophoresis, electrospray ionization, and so forth. The above techniques can detect the melamine concentration up to parts per million (ppm) range [9-15]. Major limitation is the cost of the equipment; it demands highly skilled labor and is economically and practically not feasible for routine analyses [16]. Also detection of parts per billion (ppb) or even parts per trillion (ppt) levels of melamine by advanced analytical techniques can also generate false-positive results. To overcome the above limitations, development of analytical methodologies enables in situ detection and estimation of organic contaminants involving simple sample preparation and measurement procedure. Colorimetric methods have been reported to use gold- and silver-based nanoparticles as 
TABLE 1: The concentration range of different dye solutions.

\begin{tabular}{lc}
\hline Dye & $\begin{array}{c}\text { Concentration range of melamine } \\
\left(\mathrm{mg} \mathrm{dm}^{-3}\right) \text { can be detected }\end{array}$ \\
\hline Bromophenol blue & $3-30$ \\
Alizarin red-S & $10-50$ \\
Methyl red & $41-206.8$ \\
\hline
\end{tabular}

probes, crown ether-assembled gold nanoparticles, citratecapped gold nanoparticles, and so forth [13, 17-21]. These visual methods are simpler, do not require expensive instrumentation, and have practical application for the detection of melamine but gold- and silver-based reagents are expensive. By using appropriate $\mathrm{pH}$ indicator and adjusting the $\mathrm{pH}$ of the medium, a simple and effective spectrophotometric method has been developed. The safety limit for infant milk products in US, China, and Europe has been set at $2.5 \mathrm{mg} / \mathrm{kg}$. If the melamine intake exceeds the safety limit then it will severely damage kidneys. Hence in this work, we report on the use of dye solution such as bromophenol, methyl red, and alizarin red-S as $\mathrm{pH}$ indicator for the detection of melamine in the range of 3-206 $\mathrm{mg} \mathrm{dm}^{-3}$. The increase in the melamine causes shift in the $\mathrm{pH}$ of the test system thus leading to color change. The change in colour of melamine-dye (bromophenol, methyl red, and alizarin red-S) solution is proportional to the amount of melamine present in the solution and hence a simple and economical method for the qualitative and quantitative determination of melamine has been reported.

\section{Experimental Section}

2.1. Materials. Bromophenol blue, methyl red, alizarin red-S sodium salt, and melamine were procured from commercial sources (SD-Fine Chemicals, India) and used without purification.

2.2. Sample Preparation. Stock solution of dye (bromophenol blue, methyl red, and alizarin red-S) was prepared by weighing known quantities of dyes and was made up to one litre using distilled water separately. In case of methyl red, we have used $60 \%$ water and $40 \%$ ethyl alcohol as solvent mixture. The concentrations of bromophenol dye, methyl red, and alizarin red-S solutions used for the experiments are given in Table 1.

Into a series of $100 \mathrm{~mL}$ volumetric flasks, $50 \mathrm{~mL}$ of dye solution was added to melamine solution $(50 \mathrm{~mL})$ of different concentrations (see Tables 2, 3, and 4). The mixtures were stirred well and the absorbance values were measured in the range from $335 \mathrm{~nm}$ to $1000 \mathrm{~nm}$. The concentrations of melamine are in the range from $7.0909 \times 10^{-5} \mathrm{M}$ to $1.64 \times$ $10^{-3} \mathrm{M}$ and the $\mathrm{pH}$ of the above solutions was recorded using glass electrode.

\section{Characterization}

Melamine was characterized using Bruker-D8 Advanced powder X-ray diffractometer with $\mathrm{Cu} \mathrm{K \alpha}$ source $(\lambda=$ $1.5418 \AA$, scan rate $2^{\circ} \mathrm{min}^{-1}$; steps $-0.05^{\circ}$; scan range- $10-65^{\circ}$
$2 \theta$ ) was used to determine the crystal structure. Elico $157 \mathrm{mini}$ UV-visible spectrometer was used to measure the absorbance spectra of different solutions.

\section{Results and Discussion}

Indicators are weak acids or weak bases whose conjugate base/conjugate acid exhibits different colour with change in the $\mathrm{pH}$

$$
\mathrm{H}(\text { anion })+\mathrm{H}_{2} \mathrm{O} \longleftrightarrow \text { Anion }^{-}+\mathrm{H}_{3} \mathrm{O}^{+}
$$

Several factors affect the absorbance, that is, $\mathrm{pH}$, ionic strength, concentration, volume of the solution, and so forth, of which $\mathrm{pH}$ plays an important role in most of the analytical methods especially in case of acid-base reactions which occur in aqueous medium. In view of this, the indicator must be accordingly selected to change colour when the $\mathrm{pH}$ of the test solution either increases or decreases. Indicators such as bromophenol blue, methyl red, and alizarin red-S were chosen as indicators and the structures are shown in Figure 1. Bromophenol blue $\left(\mathrm{C}_{19} \mathrm{H}_{10} \mathrm{Br}_{4} \mathrm{O}_{5} \mathrm{~S}\right.$ or $3^{\prime}, 3^{\prime \prime}, 5^{\prime}, 5^{\prime \prime}$, tetrabromophenol Sulfophathalein) is a redox indicator dye which shows colour transition in the range from 3 to 6 . The colour of bromophenol blue solution is yellow at $\mathrm{pH} 3$ and exhibits bluish purple colour at $\mathrm{pH}>4.6$. Bromophenol blue exhibits $\mathrm{pK}_{\mathrm{a}}$ values at 3.6, 3.85, and 4.0 with absorption maxima at $422 \mathrm{~nm}, 436 \mathrm{~nm}, 529 \mathrm{~nm}$, and $598 \mathrm{~nm}$ in the visible region [22]. Methyl red, $\mathrm{C}_{15} \mathrm{H}_{15} \mathrm{~N}_{3} \mathrm{O}_{2}$, is an azo dye which exhibits colour changes from red at $\mathrm{pH} 4.4$ to yellow at $\mathrm{pH}$ 6.2. They have $\mathrm{pK}_{\mathrm{a}}$ values at 2.3, 2.5, 4.95, and 5.06 [23]. Alizarin red-S is classified under anthraquinone dye which changes its yellow colour at $\mathrm{pH} 3.5$ to red at $\mathrm{pH}$ 6.5. They exhibit two $\mathrm{pK}_{\mathrm{a}}$ values at 4.5 and 11 [24]. The absorption maxima are exhibited at $423 \mathrm{~nm}, 546 \mathrm{~nm}$, and $596 \mathrm{~nm}$, respectively. The concentration of melamine has been examined for different mole ratios. The $\mathrm{pH}$ of the different concentrations of dye solutions in contact with melamine at different mole ratios leads to an increase in the $\mathrm{pH}$ due to the basic nature of melamine (see Tables 2-4). The concentration of melamine using different types of dyes (bromophenol blue, methyl red, and alizarin red-S dye) has been examined at different mole ratios. Thus a visual color change observed is proportional to the amount of melamine thus causing the change in the equilibrium resulting in a higher or basic $\mathrm{pH}$.

The melamine is alkalescence with the $\mathrm{pK}_{\mathrm{a}}$ of 5 and has no absorption in the range of 335 to $1000 \mathrm{~nm}$, while the bromophenol blue, methyl red, and alizarin red-s dye exhibit absorbance peaks at $598 \mathrm{~nm}, 520 \mathrm{~nm}$, and $400 \mathrm{~nm}$, respectively. The stoichiometric ratio of melamine-dye mixtures is shown in Tables 2-4. The concentrations of dye solution are fixed and the melamine concentration is increased. Increase in the concentration of melamine leads to the increase in the $\mathrm{pH}$ of the solution from 4 to 6.8 (see Tables 2-4). Visual detection of the colour changes may not provide accurate information about the colour transitions (see Figures 2, 3, and 4). Hence it is suitable to carry out the acceptable sensitivity for the determination of melamine by spectrophotometric estimation. 
TABLE 2: Variation in the mole ratio of bromophenol blue dye and melamine solutions and $\mathrm{pH}$.

\begin{tabular}{|c|c|c|c|}
\hline \multirow{2}{*}{$\begin{array}{l}\text { Mole ratio of bromophenol blue and } \\
\text { melamine (total volume }-100 \mathrm{~mL} \text { ) }\end{array}$} & \multicolumn{2}{|c|}{ Concentration } & \multirow{2}{*}{$\mathrm{pH}$} \\
\hline & Bromophenol blue (M) & Melamine (M) & \\
\hline Melamine & - & $2.37 \times 10^{-5}\left(3 \mathrm{mg} \mathrm{dm}^{-3}\right)$ & 6.18 \\
\hline Bromophenol blue & $2.37 \times 10^{-5}\left(15 \mathrm{mg} \mathrm{dm}^{-3}\right)$ & - & 4.9 \\
\hline $1: 1$ & $2.37 \times 10^{-5}\left(15 \mathrm{mg} \mathrm{dm}^{-3}\right)$ & $2.37 \times 10^{-5}\left(3 \mathrm{mg} \mathrm{dm}^{-3}\right)$ & 4.92 \\
\hline $1: 2$ & $2.37 \times 10^{-5}\left(15 \mathrm{mg} \mathrm{dm}^{-3}\right)$ & $4.75 \times 10^{-5}\left(6 \mathrm{mg} \mathrm{dm}^{-3}\right)$ & 4.95 \\
\hline $1: 4$ & $2.37 \times 10^{-5}\left(15 \mathrm{mg} \mathrm{dm}^{-3}\right)$ & $9.51 \times 10^{-5}\left(12 \mathrm{mg} \mathrm{dm}^{-3}\right)$ & 5.24 \\
\hline $1: 6$ & $2.37 \times 10^{-5}\left(15 \mathrm{mg} \mathrm{dm}^{-3}\right)$ & $1.268 \times 10^{-4}\left(16 \mathrm{mg} \mathrm{dm}^{-3}\right)$ & 5.55 \\
\hline $1: 8$ & $2.37 \times 10^{-5}\left(15 \mathrm{mg} \mathrm{dm}^{-3}\right)$ & $1.9029 \times 10^{-4}\left(24 \mathrm{mg} \mathrm{dm}^{-3}\right)$ & 5.73 \\
\hline $1: 10$ & $2.37 \times 10^{-5}\left(15 \mathrm{mg} \mathrm{dm}^{-3}\right)$ & $2.378 \times 10^{-4}\left(30 \mathrm{mg} \mathrm{dm}^{-3}\right)$ & 5.85 \\
\hline
\end{tabular}

TABLE 3: Variation in the concentration of melamine and methyl red dye solutions and $\mathrm{pH}$.

\begin{tabular}{|c|c|c|c|}
\hline \multirow{2}{*}{$\begin{array}{l}\text { Mole ratio of methyl red and melamine } \\
\text { (total volume }-100 \mathrm{~mL} \text { ) }\end{array}$} & \multicolumn{2}{|c|}{ Concentration } & \multirow{2}{*}{$\mathrm{pH}$} \\
\hline & Methyl red (M) & Melamine (M) & \\
\hline Melamine & - & $7.909 \times 10^{-5}\left(10 \mathrm{mg} \mathrm{dm}^{-3}\right)$ & 6.32 \\
\hline Methyl red & $7.909 \times 10^{-5}\left(10 \mathrm{mg} \mathrm{dm}^{-3}\right)$ & - & 5.03 \\
\hline $1: 1$ & $7.909 \times 10^{-5}\left(10 \mathrm{mg} \mathrm{dm}^{-3}\right)$ & $7.909 \times 10^{-5}\left(10 \mathrm{mg} \mathrm{dm}^{-3}\right)$ & 5.36 \\
\hline $1: 2$ & $7.909 \times 10^{-5}\left(10 \mathrm{mg} \mathrm{dm}^{-3}\right)$ & $1.781 \times 10^{-4}\left(20 \mathrm{mg} \mathrm{dm}^{-3}\right)$ & 5.68 \\
\hline $1: 3$ & $7.909 \times 10^{-5}\left(10 \mathrm{mg} \mathrm{dm}^{-3}\right)$ & $2.372 \times 10^{-4}\left(30 \mathrm{mg} \mathrm{dm}^{-3}\right)$ & 5.89 \\
\hline $1: 4$ & $7.909 \times 10^{-5}\left(10 \mathrm{mg} \mathrm{dm}^{-3}\right)$ & $3.163 \times 10^{-4}\left(40 \mathrm{mg} \mathrm{dm}^{-3}\right)$ & 6.06 \\
\hline $1: 5$ & $7.909 \times 10^{-5}\left(10 \mathrm{mg} \mathrm{dm}^{-3}\right)$ & $3.954 \times 10^{-4}\left(50 \mathrm{mg} \mathrm{dm}^{-3}\right)$ & 6.21 \\
\hline
\end{tabular}

TABLE 4: Variation in the mole ratio of melamine and alizarin red dye solutions and $\mathrm{pH}$.

\begin{tabular}{|c|c|c|c|}
\hline \multirow{2}{*}{$\begin{array}{l}\text { Mole ratio of alizarin red and melamine } \\
\text { (total volume }-100 \mathrm{~mL} \text { ) }\end{array}$} & \multicolumn{2}{|c|}{ Concentration } & \multirow{2}{*}{$\mathrm{pH}$} \\
\hline & Alizarin red $(\mathrm{M})$ & Melamine (M) & \\
\hline Melamine & - & $3.29 \times 10^{-4}\left(41.5 \mathrm{mg} \mathrm{dm}^{-3}\right)$ & 6.19 \\
\hline Alizarin red-S & $3.29 \times 10^{-4}\left(41.5 \mathrm{mg} \mathrm{dm}^{-3}\right)$ & - & 4.49 \\
\hline $1: 1$ & $3.29 \times 10^{-4}\left(41.5 \mathrm{mg} \mathrm{dm}^{-3}\right)$ & $3.29 \times 10^{-4}\left(41.5 \mathrm{mg} \mathrm{dm}^{-3}\right)$ & 5.18 \\
\hline $1: 2$ & $3.29 \times 10^{-4}\left(41.5 \mathrm{mg} \mathrm{dm}^{-3}\right)$ & $6.58 \times 10^{-4}\left(83 \mathrm{mg} \mathrm{dm}^{-3}\right)$ & 5.46 \\
\hline $1: 3$ & $3.29 \times 10^{-4}\left(41.5 \mathrm{mg} \mathrm{dm}^{-3}\right)$ & $9.87 \times 10^{-4}\left(124.5 \mathrm{mg} \mathrm{dm}^{-3}\right)$ & 5.65 \\
\hline $1: 4$ & $3.29 \times 10^{-4}\left(41.5 \mathrm{mg} \mathrm{dm}^{-3}\right)$ & $1.31 \times 10^{-3}\left(165.2 \mathrm{mg} \mathrm{dm}^{-3}\right)$ & 5.71 \\
\hline $1: 5$ & $3.29 \times 10^{-4}\left(41.5 \mathrm{mg} \mathrm{dm}^{-3}\right)$ & $1.64 \times 10^{-3}\left(206.8 \mathrm{mg} \mathrm{dm}^{-3}\right)$ & 5.82 \\
\hline
\end{tabular}

Figures 5-7 illustrate the change of absorption spectra of melamine-dye mixtures at different mole ratios with the dye concentration fixed. The colour of the bromophenol blue dye solution is violet and in presence of melamine at higher concentrations changes to navy blue (see Figure 5). The absorption maxima for bromophenol blue dye solution are observed at $598 \mathrm{~nm}$ and increase with increase in the melamine concentration (1:10) (see Figure 5). In case of methyl red dye, the colour of the solution is light red and its intensity increases when large concentration/quantity of melamine is added (see Figure 6). We observe decrease in the intensity of peak at $520 \mathrm{~nm}$ and new peak emerges at $420 \mathrm{~nm}$ when methyl red and melamine are mixed in different mole ratios (see Figure 6) (melamine : methyl red ratio $1: 5$ ). In case of alizarin red-S dye solution, the peak was observed at $400 \mathrm{~nm}$ and shifts to $423 \mathrm{~nm}$; a new peak at $520 \mathrm{~nm}$ emerges (see Figure 7). We have evaluated the change in the absorbance in different dye solutions with increase in the melamine concentration, while alizarin red dye exhibits yellowish orange and changes to wine red in presence of melamine (see Figure 7). Figures 8, 9, and 10 show UV-visible spectroscopic response of different types of dyes with melamine at different ratios. A strong linear correlation was obtained by the absorbance of the methyl red dye solution with increase in the melamine concentration at $\lambda=520-527 \mathrm{~nm}$ and the correlation coefficient was 0.99 (see Figure 11), while in case of alizarin red-S it is not linear in nature. The change in the absorbance of bromophenol with increase in the concentration of melamine shows contrasting data compared to methyl red dye-melamine solutions (see Figures 12 and 13). Thus we observe significant change in the colour of dye with changes in the melamine concentration.

\section{Conclusion}

A simple spectrophotometric method for the determination of trace quantities of melamine in aqueous solution has been 
<smiles>Nc1nc(N)nc(N)n1</smiles>

(a)<smiles>CN(C)c1ccc(/N=N/c2ccccc2C(=O)O)cc1</smiles>

(b)<smiles>NS(=O)(=O)c1cc2c(c(O)c1O)C(=O)c1ccccc1C2=O</smiles>

(c)<smiles>O=S1(=O)OC(c2cc(Br)c(O)c(Br)c2)(c2cc(Br)c(O)c(Br)c2)c2ccccc21</smiles>

(d)

FIGURE 1: Structures of melamine and dyes.

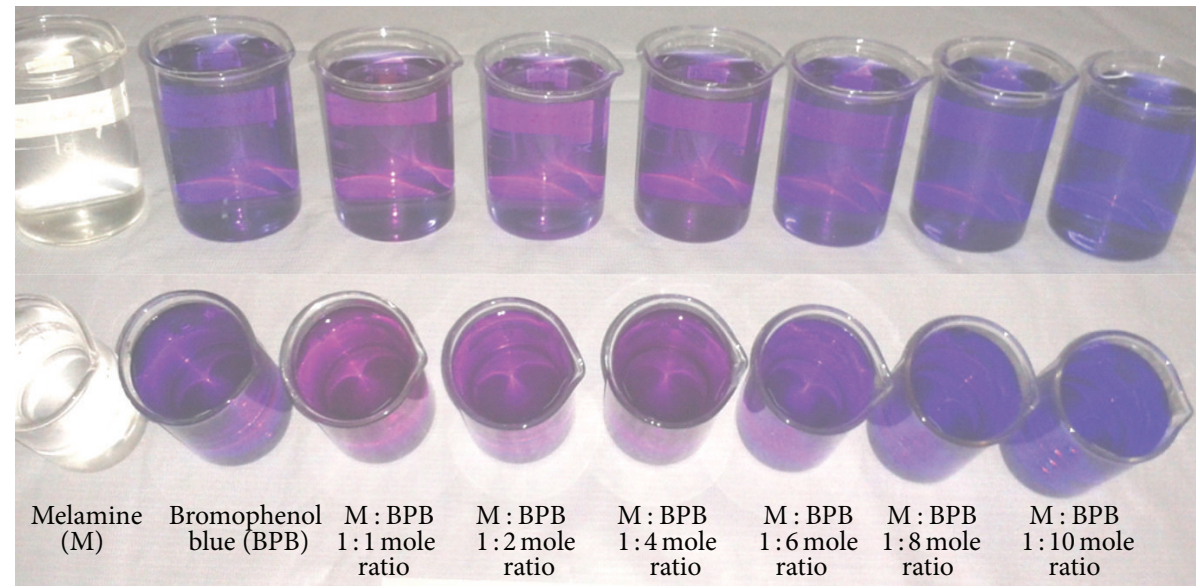

FIgURE 2: Melamine and bromophenol blue solution mixtures at different mole ratios.

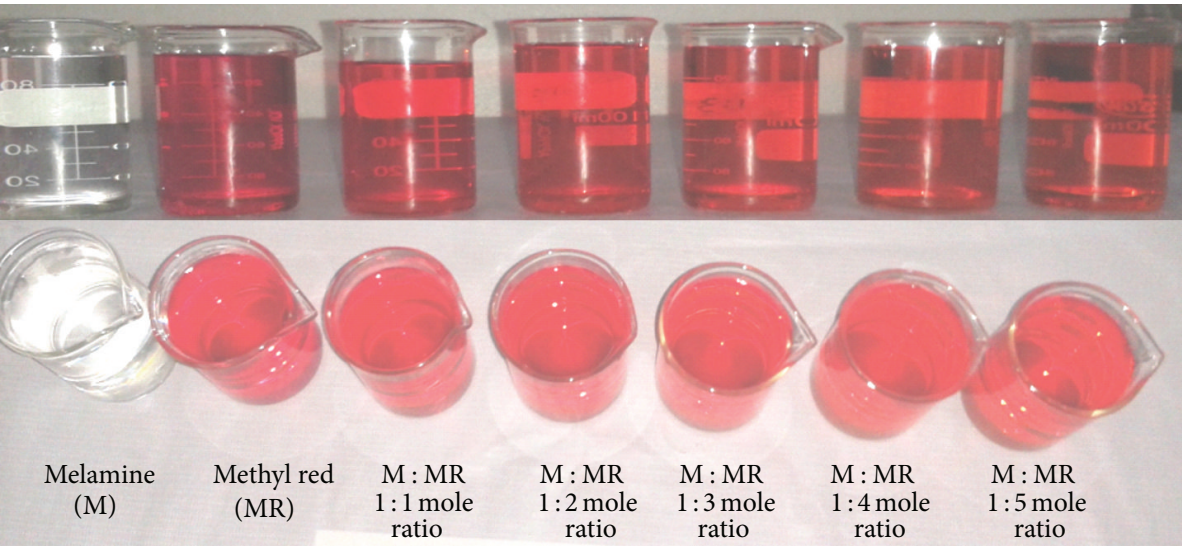

Figure 3: Melamine and methyl red solution mixture at different mole ratios. 


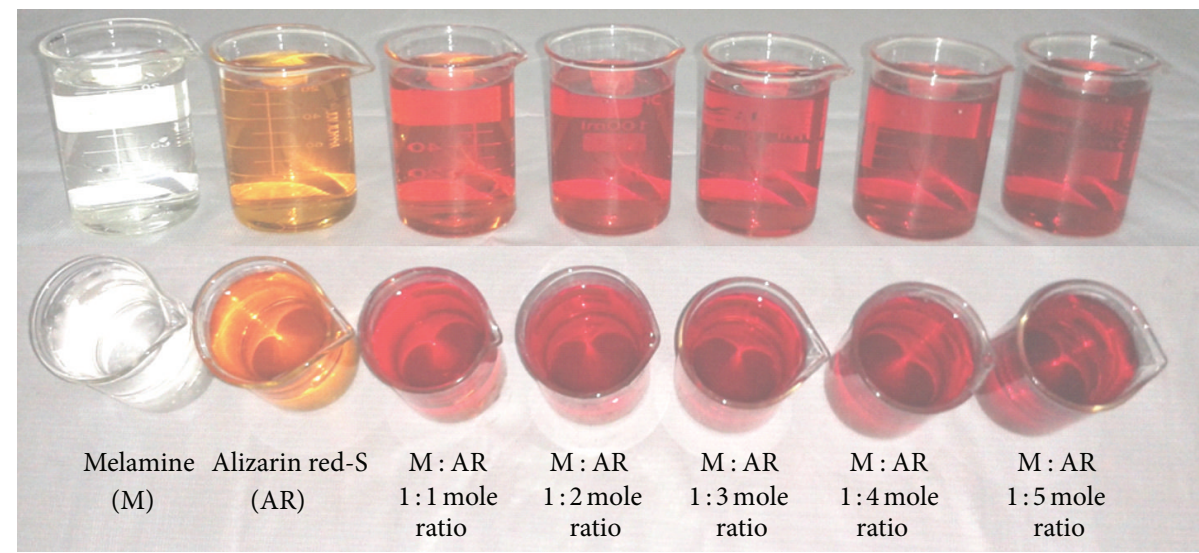

FIgURE 4: Melamine and alizarin red solution mixture at different mole ratios.

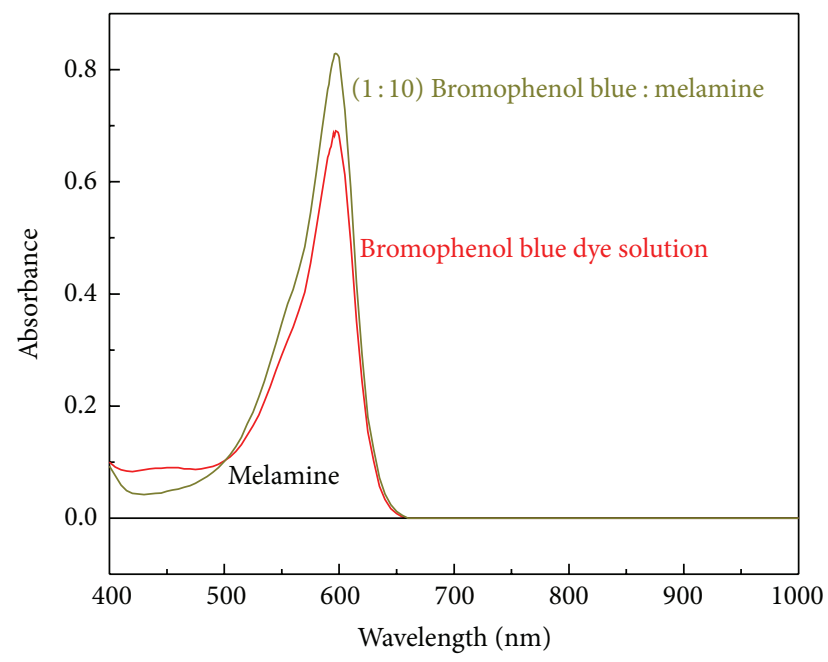

Figure 5: Absorption spectra of melamine, bromophenol blue dye, and mixture of melamine and bromophenol blue solutions at $1: 10$ mole ratio.

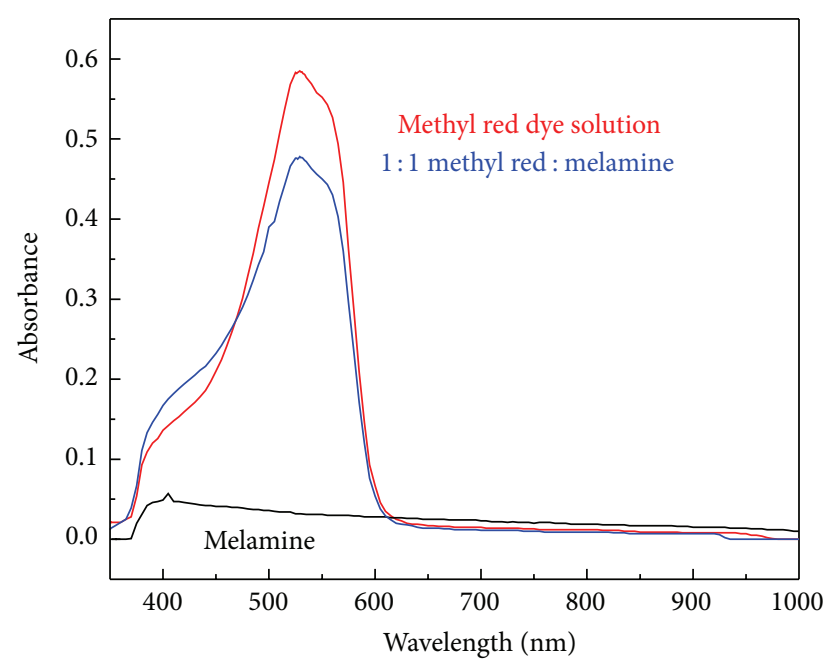

FIGURE 6: Absorption spectra of melamine, methyl red dye, and mixture of melamine and methyl red dye solutions at $1: 1$ mole ratio.

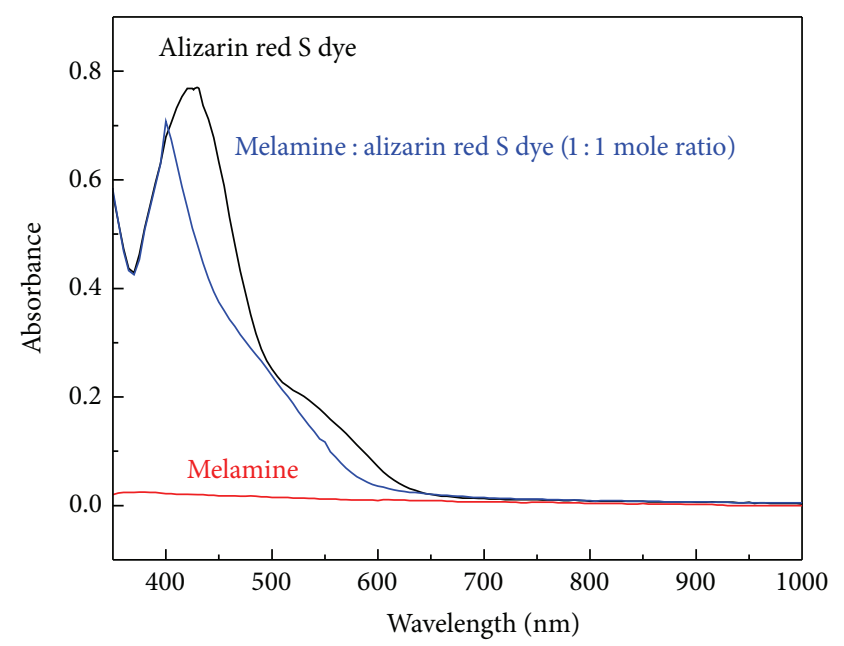

FIgURE 7: Absorption spectra of melamine, alizarin red dye, and mixture of melamine and alizarin red dye solutions at $1: 1$ mole ratio.

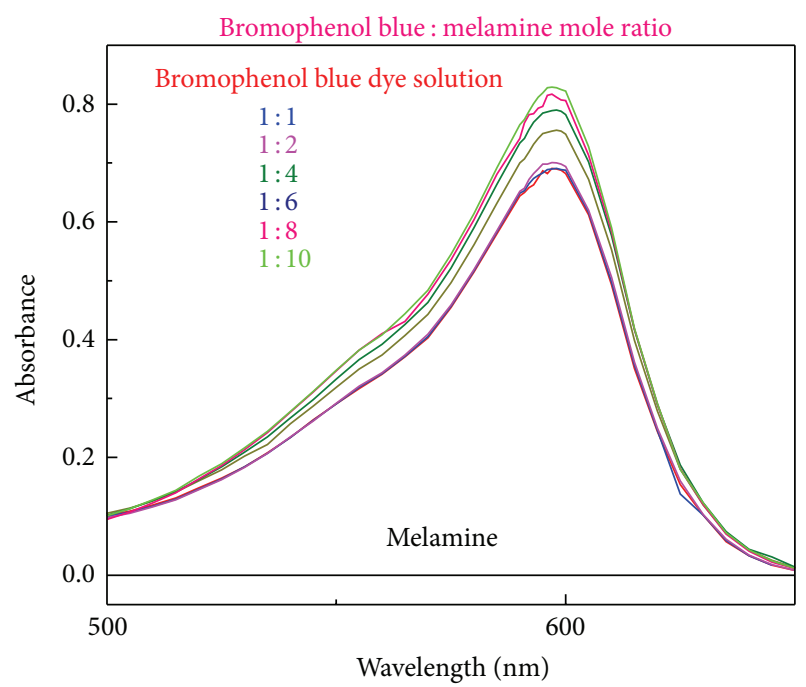

FIGURE 8: Absorption spectra of melamine, bromophenol blue dye, and mixture of melamine and bromophenol blue solution at different mole ratios. 


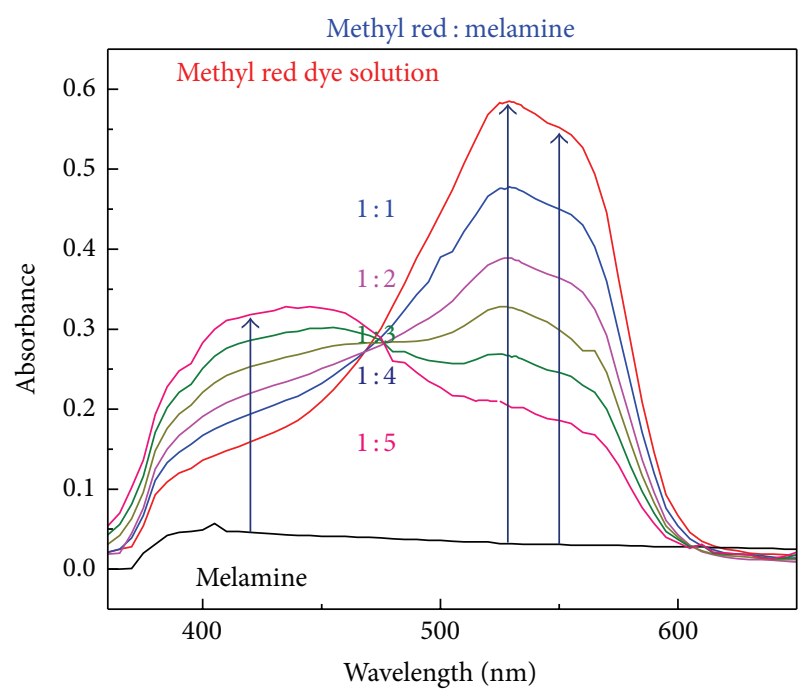

FIGURE 9: Absorption spectra of melamine, methyl red dye, and mixture of melamine and methyl red dye solution at different mole ratios.

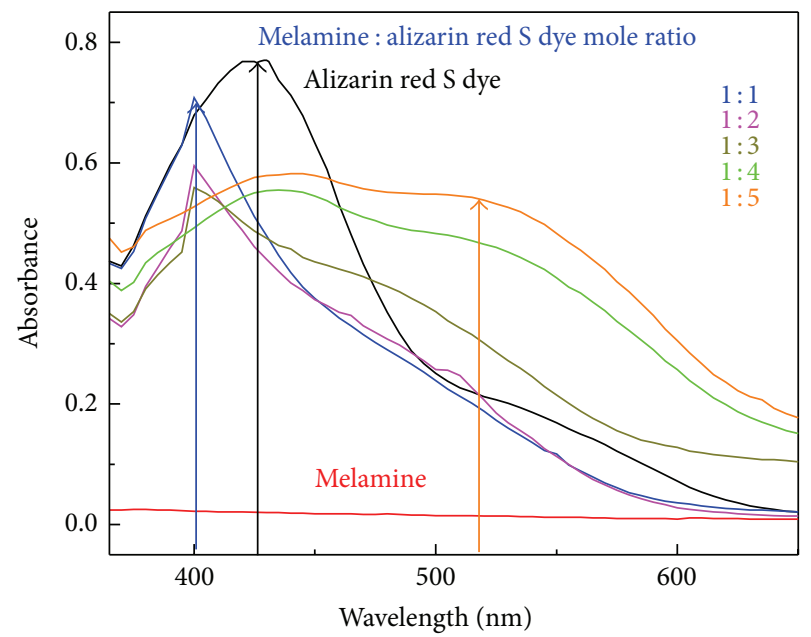

FIGURE 10: Absorption spectra of melamine, alizarin red dye, and mixture of melamine and alizarin red dye solution at different mole ratios.

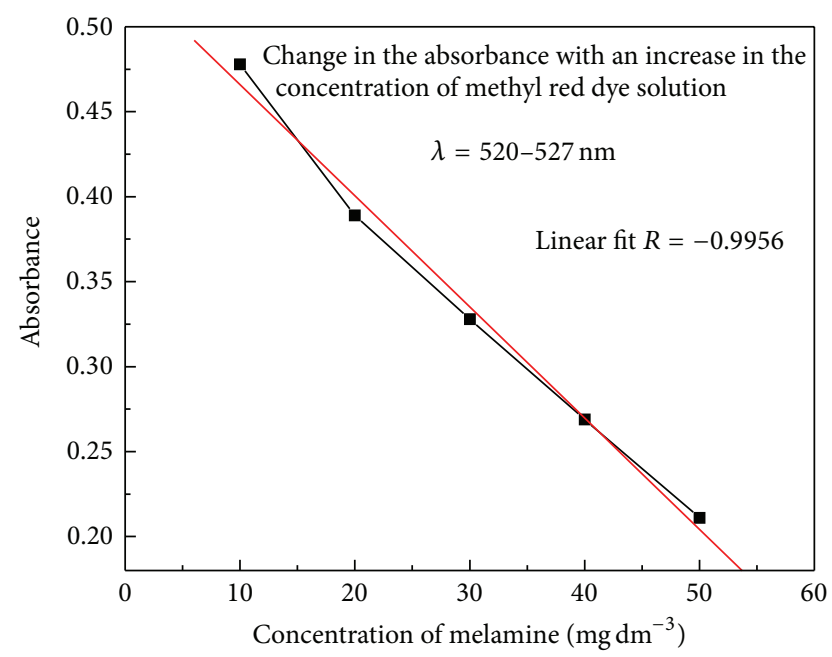

FIGURE 11: Linear absorbance as a function of concentration of melamine with methyl red dye.

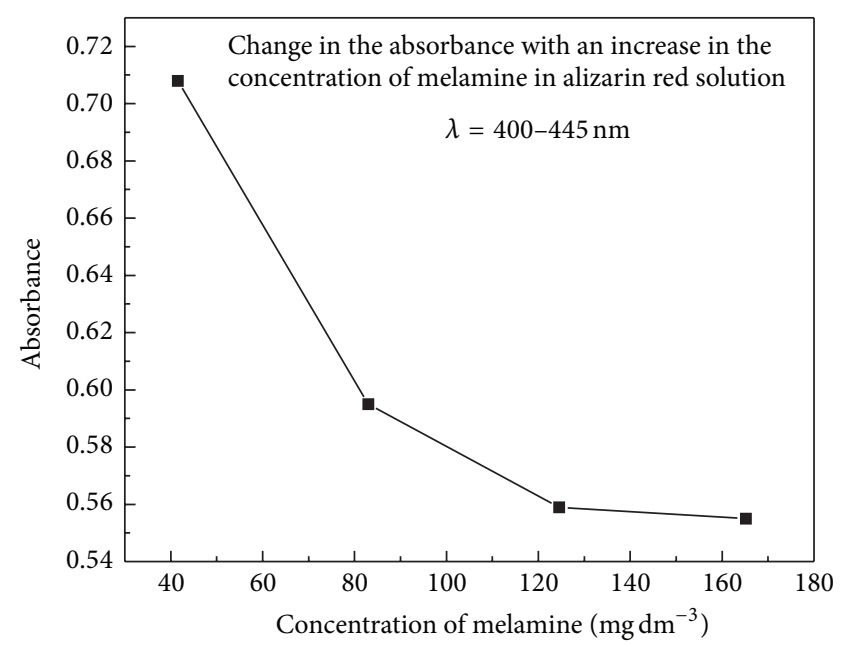

FIGURE 12: Absorbance as a function of concentration of melamine with alizarin red dye.

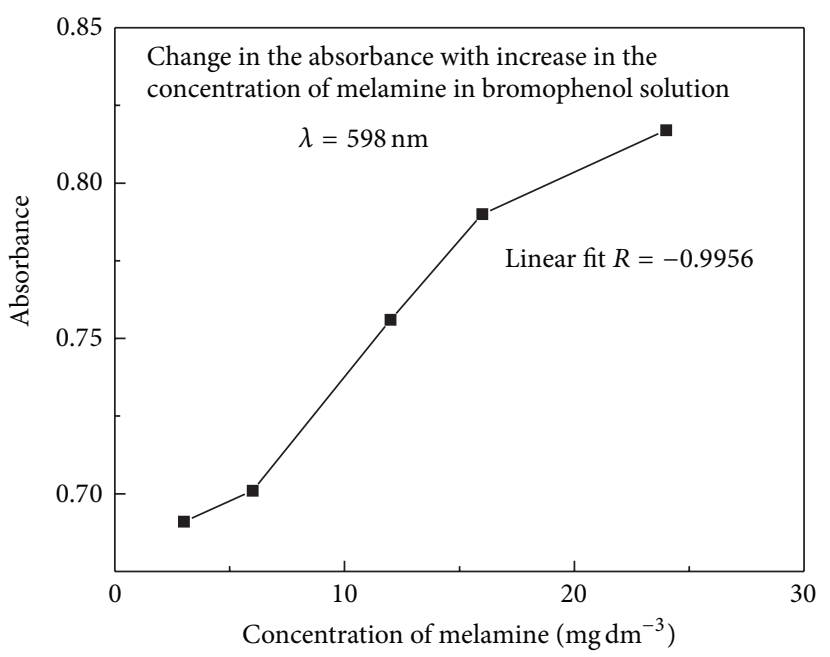

FIGURE 13: Linear absorbance as a function of concentration of melamine with bromophenol blue dye.

reported. The method involves interaction of melamine based on the acid-base reaction with different types of dyes. The colour change is due to the variation in the $\mathrm{pH}$ of the aqueous solution containing dye solution. The synthetic dyes can transform molecular recognition between the $\mathrm{pK}_{\mathrm{a}}$ and their interaction with weak base melamine into the visual color change. The proposed method can be used for the detection of melamine in the range from 3 to $206 \mathrm{mg} \mathrm{dm}^{-3}$ using different dyes.

\section{Conflict of Interests}

The authors declare that there is no conflict of interests regarding the publication of this paper.

\section{Acknowledgments}

Ramesh Thimmasandra Narayan wishes to thank Professor P. Vishnu Kamath, Bangalore University, for providing 
laboratory facilities and his unconditional support and constant encouragement throughout the career. The author would like to thank Tumkur University for the facilities.

\section{References}

[1] E. D. Weil and V. Choudhary, "Flame-retarding plastics and elastomers with melamine," Journal of Fire Science, vol. 13, no. 2, pp. 104-126, 1995.

[2] T. Sugita, H. Ishiwata, and K. Yoshihira, "Release of formaldehyde and melamine from tableware made of melamineformaldehyde resin," Food Additives and Contaminants, vol. 7, no. 1, pp. 21-27, 1990.

[3] A. M. Grabiec, "Contribution to the knowledge of melamine superplasticizer effect on some characteristics of concrete after long periods of hardening," Cement and Concrete Research, vol. 29, no. 5, pp. 699-704, 1999.

[4] R. D. Hauck and H. F. Stephenson, "Nitrification of triazine nitrogen," Journal of Agricultural and Food Chemistry, vol. 12, no. 2, pp. 147-151, 1964.

[5] USEPA, “Cyromazine; pesticide tolerance," (United States Environmental Protection Agency) Federal Register, vol. 64, p. 50043, 1999.

[6] L. Zhang, L.-L. Wu, Y.-P. Wang, A.-M. Liu, C.-C. Zou, and Z.-Y. Zhao, "Melamine-contaminated milk products induced urinary tract calculi in children," World Journal of Pediatrics, vol. 5, no. 1, pp. 31-35, 2009.

[7] S. Ehling, S. Tefera, and I. P. Ho, "High-performance liquid chromatographic method for the simultaneous detection of the adulteration of cereal flours with melamine and related triazine by-products ammeline, ammelide, and cyanuric acid," Food Additives and Contaminants, vol. 24, no. 12, pp. 1319-1325, 2007.

[8] C. M.-E. Gossner, J. Schlundt, P. B. Embarek et al., "The melamine incident: implications for international food and feed safety," Environmental Health Perspectives, vol. 117, no. 12, pp. 1803-1808, 2009.

[9] C. A. J. Brown, "Outbreaks of renal failure associated with melamine and cyanuric acid in dogs and cats in 2004 and 2007," Journal of Veternary Diagnostic Investigation, vol. 19, no. 5, pp. 525-531, 2004.

[10] F. N. Ihunegbo, S. Tesfalidet, and W. Jiang, "Determination of melamine in milk powder using zwitterionic HILIC stationary phase with UV detection," Journal of Separation Science, vol. 33, no. 6-7, pp. 988-995, 2010.

[11] H. A. Cook, C. W. Klampfl, and W. Buchberger, "Analysis of melamine resins by capillary zone electrophoresis with electrospray ionization-mass spectrometric detection," Electrophoresis, vol. 26, no. 7-8, pp. 1576-1583, 2005.

[12] A. J. Dane and R. B. Cody, "Selective ionization of melamine in powdered milk by using argon direct analysis in real time (DART) mass spectrometry," Analyst, vol. 135, no. 4, pp. 696699, 2010 .

[13] L. Li, B. Li, D. Cheng, and L. Mao, "Visual detection of melamine in raw milk using gold nanoparticles as colorimetric probe," Food Chemistry, vol. 122, no. 3, pp. 895-900, 2010.

[14] L. J. Mauer, A. A. Chernyshova, A. Hiatt, A. Deering, and R. Davis, "Melamine detection in infant formula powder using near- and mid-infrared spectroscopy," Journal of Agricultural and Food Chemistry, vol. 57, no. 10, pp. 3974-3980, 2009.

[15] Q. Wang, S. A. Haughey, Y.-M. Sun et al., "Development of a fluorescence polarization immunoassay for the detection of melamine in milk and milk powder," Analytical and Bioanalytical Chemistry, vol. 399, no. 6, pp. 2275-2284, 2011.

[16] J. Xia, N. Zhou, Y. Liu, B. Chen, Y. Wu, and S. Yao, "Simultaneous determination of melamine and related compounds by capillary zone electrophoresis," Food Control, vol. 21, no. 6, pp. 912-918, 2010.

[17] H. Kuang, W. Chen, W. Yan et al., "Crown ether assembly of gold nanoparticles: melamine sensor," Biosensors and Bioelectronics, vol. 26, no. 5, pp. 2032-2037, 2011.

[18] W. J. Qi, D. Wu, J. Ling, and C. Z. Huang, "Visual and light scattering spectrometric detections of melamine with polythyminestabilized gold nanoparticles through specific triple hydrogenbonding recognition," Chemical Communications, vol. 46, no. 27, pp. 4893-4895, 2010.

[19] H. Chi, B. Liu, G. Guan, Z. Zhang, and M.-Y. Han, "A simple, reliable and sensitive colorimetric visualization of melamine in milk by unmodified gold nanoparticles," Analyst, vol. 135, no. 5, pp. 1070-1075, 2010.

[20] Z. H. Qin, H. W. Zhao, C. Z. Huang, and L. P. Wu, "Visual detection of melamine in raw milk by label-free silver nanoparticles," Chemistry Letters, vol. 38, pp. 470-471, 2009.

[21] X. S. Liang, H. P. Wei, Z. Q. Cui, J. Y. Deng, Z. P. Zhang, and X. Y. You, "One-step synthesis of silver/dopamine nanoparticles and visual detection of melamine in raw milk," Analyst, vol. 136, pp. 179-183, 2010.

[22] I. M. Kolthoff, Acid Base Indictors, Read Books, 2007.

[23] R. W. Sabnis, Handbook of Acid-Base Indicators, CRC Press, Boco Raton, Fla, USA, 2008.

[24] R. E. Davis, M. L. Peck, and G. S. George, Chemistry, Cenage Learning, 2010. 

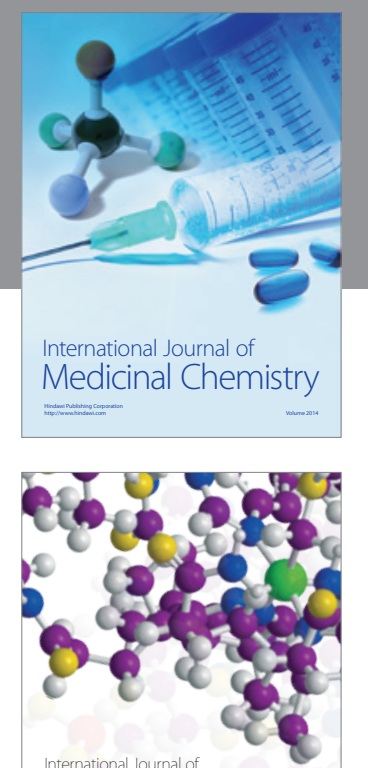

\section{Carbohydrate} Chemistry

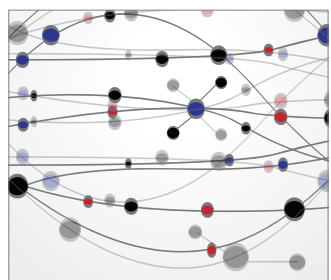

The Scientific World Journal
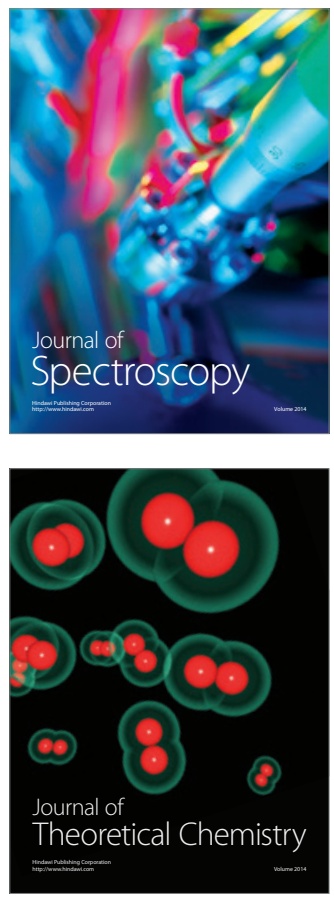
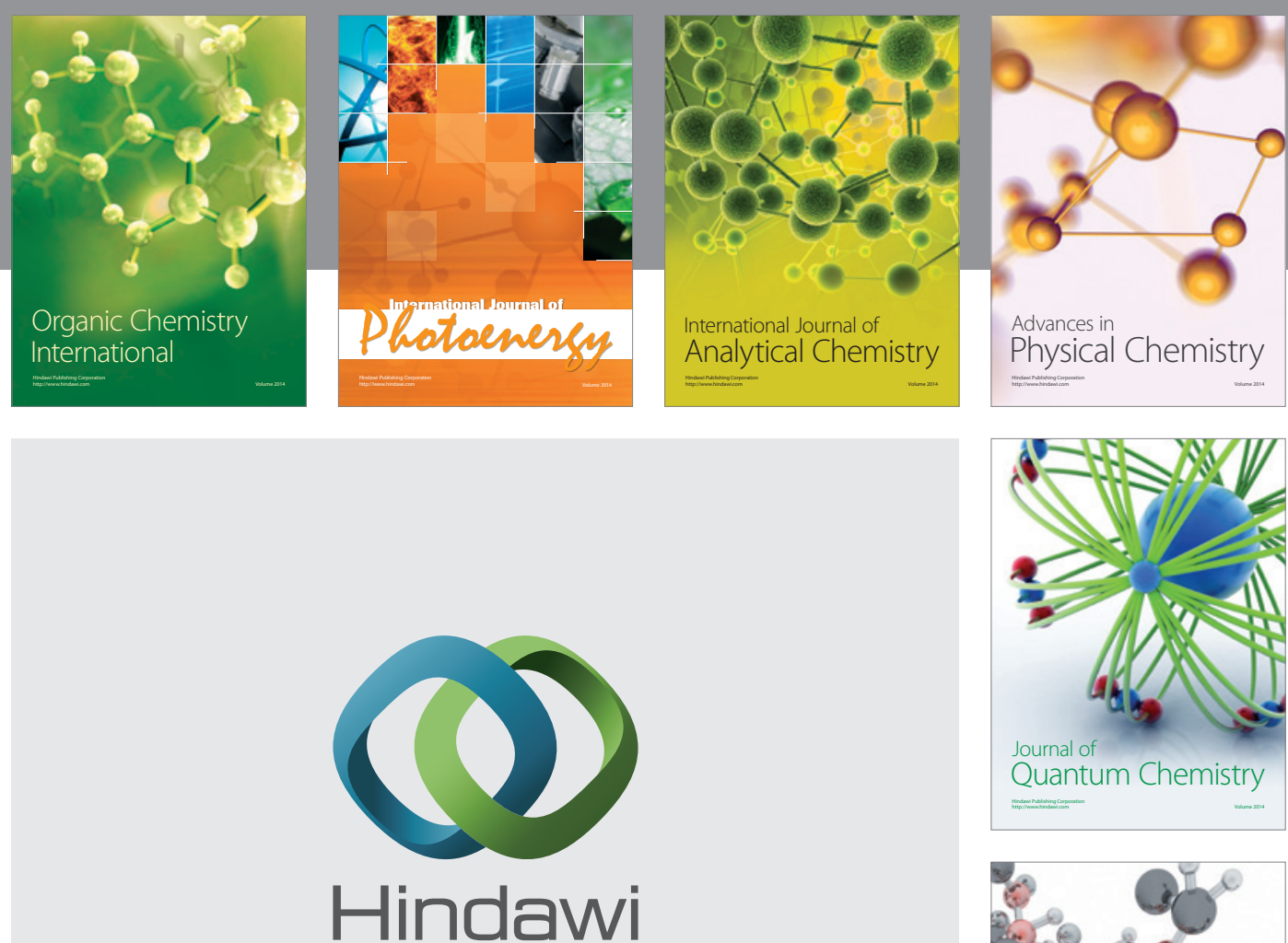

Submit your manuscripts at

http://www.hindawi.com

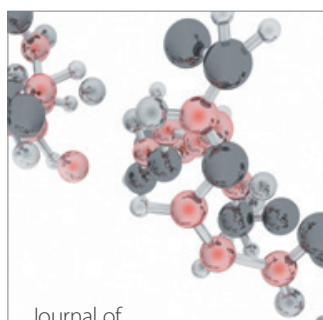

Analytical Methods

in Chemistry

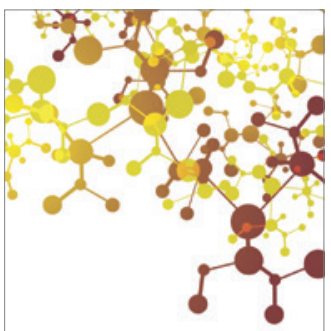

Journal of

Applied Chemistry

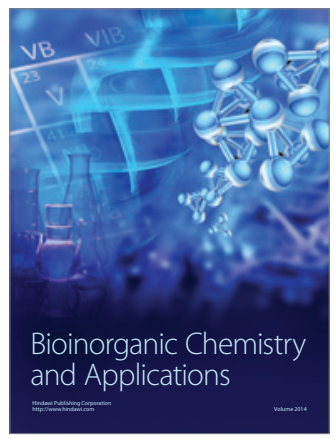

Inorganic Chemistry
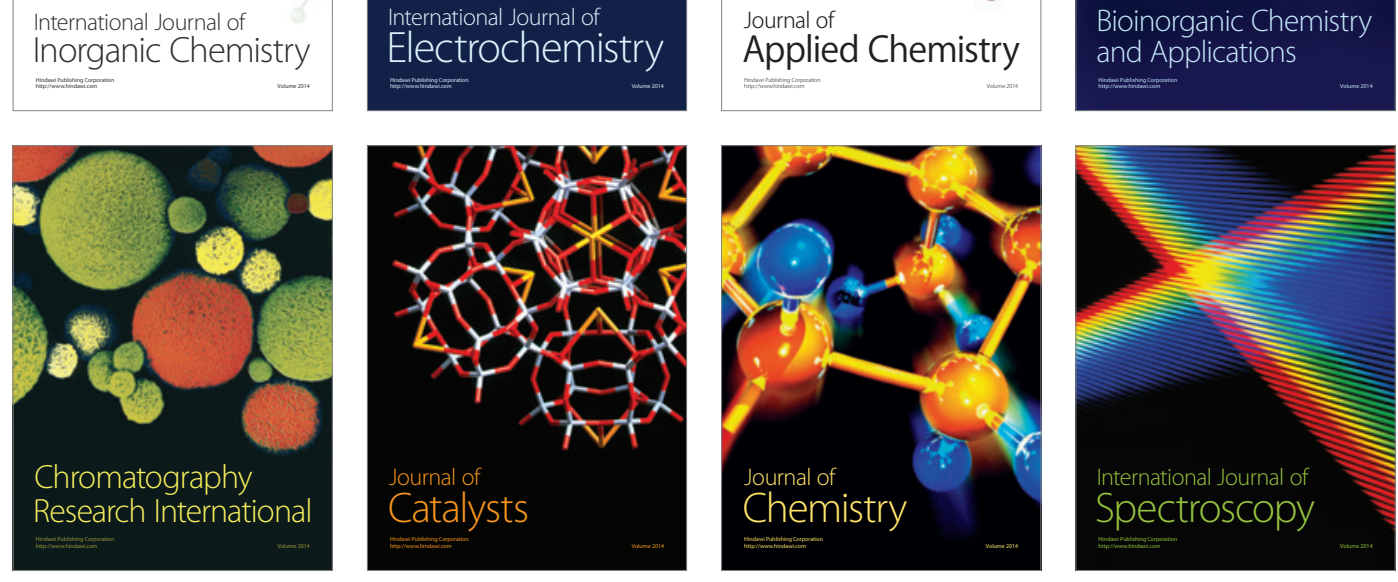